\title{
Risky Behaviour among Nurses in Poland: An Analysis of Nurses' Physical Condition, Mental Health, and Resilience
}

\author{
Lucyna Gieniusz-Wojczyk ${ }^{1, *}$, Józefa Dąbek ${ }^{2}$ and Halina Kulik ${ }^{1}$ \\ 1 Department of Propaedeutics of Nursing, School of Health Sciences in Katowice, Medical University of Silesia \\ in Katowice, 20/24 Francuska Street, 40027 Katowice, Poland; hkulik@sum.edu.pl \\ 2 Department of Cardiology, School of Health Sciences in Katowice, Medical University of Silesia in Katowice, \\ 45/47 Ziołowa Street, 40635 Katowice, Poland; jdabek@sum.edu.pl \\ * Correspondence: lucygieniusz@poczta.onet.pl
}

Citation: Gieniusz-Wojczyk, L.; Dąbek, J.; Kulik, H. Risky Behaviour among Nurses in Poland: An Analysis of Nurses' Physical Condition, Mental Health, and Resilience. Int. J. Environ. Res. Public Health 2021, 18, 1807. https:// doi.org/10.3390/ijerph18041807

Received: 13 December 2020

Accepted: 4 February 2021

Published: 12 February 2021

Publisher's Note: MDPI stays neutral with regard to jurisdictional claims in published maps and institutional affiliations.

Copyright: (c) 2021 by the authors. Licensee MDPI, Basel, Switzerland. This article is an open access article distributed under the terms and conditions of the Creative Commons Attribution (CC BY) license (https:// creativecommons.org/licenses/by/ $4.0 /)$.

\begin{abstract}
Background: Nursing is a profession where staff are exposed to chronic stress. Mental resilience plays a significant role in the process of coping with these challenges. The aim of this study was to assess nurses' mental and physical wellbeing, as well as resilience, by taking into account the occurrence of risky behaviour among nurses in Poland. Methods: A descriptive study was carried out between June 2017 and May 2018 among nurses $(n=1080)$ employed in primary healthcare or in training centres in Silesia, Poland. Data were obtained from a number of questionnaires. Results: Over half of the nurses $(n=735 ; 68 \%)$ had an average psychophysical mood level resulting from stress, and 179 (16.6\%) nurses had a low psychophysical mood. Those with a lower psychophysical mood showed a greater tendency towards developing improper eating habits $(r=-0.23 ; p<0.001)$. Most nurses had an average $(n=649 ; 60.1 \%)$ or low $(n=255 ; 23.6 \%)$ level of resilience. Higher resilience levels were observed in nurses aged over 30 years $(p=0.004)$ and in those with additional employment $(p=0.008)$. High resilience was associated with a lower intensity of risky behaviour. Conclusion: Most nurses in Poland display average and low levels of resilience, which can have unfavourable consequences for their health.
\end{abstract}

Keywords: nurse; resilience; wellbeing; health; smoking; alcohol abuse; eating habits

\section{Introduction}

The current global nursing shortages have become a global challenge for health organisations, clinicians, scientists, and nursing teachers [1]. Nurses are the largest professional group among healthcare professionals [2], and, in comparison to healthcare professionals in general, they are the most exposed to stress [3]. Improper stress management can have a negative impact on nurses' mood, resulting in depression, dissatisfaction with their job, reduced organisational loyalty, and planning to quit work, consequently leading to professional burnout and/or various diseases [4-7]. Experiencing strong or chronic stress may also contribute to an increase in risky behaviour (e.g., alcohol abuse, smoking, and poor diet). Studies show that nurses in many countries consume more alcohol [8], smoke more [9], and are more obese in comparison to the population in general [8] or employees from other sectors [10]. Such poor lifestyle choices not only affect nurses' professional performance but also increase the burden on our healthcare system since these are all key risk factors for the development of chronic diseases, such as cardiovascular diseases, hypertension, or type 2 diabetes [11,12]. Resilience is recognised as the personal capacity to effectively adapt to difficult situations. It can be defined as a personality trait or a dynamic process. The common denominator of various attitudes consists of the assessment of resilience as a property which enables people to maintain an optimum level of effective performance and to cope with failures quickly and easily, despite the difficulties encountered [13], which can be considered an alternative method of alleviating hardship in the workplace. Resilience is also perceived as an important pro-health resource [14,15]. 
High resilience is conducive to experiencing more positive emotions, such as gratitude, interest, or love, and a lower intensity of negative emotionality (anger, sadness, or fear) [16]. Resilience as a personal resource is used in professional situations [17]. Resilience can protect an individual against stress [18]. Bearing in mind that stress often leads to using stimulants in order to alleviate its effects, it can be assumed that resilience will protect nurses against excessive preoccupation with eating, excessive alcohol consumption, and smoking. Bad habits have a special place among the ways of coping with stress. They mainly serve the function of regulating one's emotional state [19]. According to the Lazarus and Folkman concept, coping with stress is a constantly evolving cognitive and behavioural effort directed to specific external and/or internal requirements that are assessed as aggravating or exceeding human capabilities [20]. So far, little research has focused on the influence of personality factors (resilience) on risky behaviour. This is undoubtedly one of the first reports showing how the features of mental resilience can influence the behaviour of nurses in Poland.

This study aimed to assess the psychophysical wellbeing and level of resilience among Polish nurses. We also explored the associations between wellbeing and resilience levels and the occurrence of risky behaviour in nurses, such as smoking, excessive alcohol consumption, and poor diet.

\section{Materials and Methods}

\subsection{Design and Participants}

This was a descriptive, multicentre study carried out between June 2017 and May 2018 in the following healthcare units and training centres for nurses in Silesia: Provincial Specialist Hospital no. 4 in Bytom, The Kornel Gibiński University Teaching Centre at Silesian Medical University in Katowice, Nursing and Midwifery Training Centre in Łagiewniki, and Postgraduate Nursing and Midwifery Training Centre in Krosno. A total of 1064 nurses were included in the study on the basis of an estimation of the size of the nursing population in Poland $(n=288,395)$ (Supreme Chamber of Nurses and Midwives, 2017) (the size of fraction $=0.5$; the level of confidence $=95 \%$; maximum error $=3 \%$ ).

All nurses were informed about the purpose and nature of the research, as well as the application of the obtained results. All participants consciously and voluntarily gave their consent to participate in the research. The research included nurses holding a diploma with the professional title of nurse who had been in the profession for at least 1 year. Pregnant women, those who had practised for less than 1 year, and those who did not give their informed consent were excluded.

The Bioethical Committee at the Silesian Medical University in Katowice approved the study (KNW 0022/KB/89/1/17). All participants gave their consent to be included in the study by returning completed, anonymous questionnaires.

After meeting the aforementioned criteria, participants were provided with the survey in an envelope. After completing the survey, the respondent returned it to the researcher.

The questionnaire contained questions concerning demographic data (age, sex, length of service, type of ward, marital status, and additional employment). It also contained a Polish version of the AUDIT-C test (the Alcohol Use Disorders Identification Test for Consumption; https: / / auditscreen.org (accessed on 12 December 2020)) to identify alcoholism [21]. In particular, women who consume $\geq 2$ units at a time or men who consume $>4$ units at a time are considered at risk of harmful drinking [21-23]. The study also included the Polish adaptation of the Fagerström test for nicotine addiction for the assessment of smoking rates (Cronbach's alpha of 0.820). The Fagerström test evaluates pharmacological addiction to nicotine. Collecting 7 or more points indicated that the individual is probably pharmacologically addicted to nicotine, while getting below 7 points means that smoking is a learned behaviour [24,25]. It also contained the questionnaire "My Eating Habits" (MEH) by Nina Ogińska-Bulik and Leszek Putyński (Cronbach's alpha of 0.89) [26] which consisted of 30 statements. Each diagnostic answer scores 1 point. The total number of points enables one to determine a general tendency for improper eating 
habits (a high score obtained in the questionnaire points to improper eating habits, i.e., the tendency to overeat or abstain from eating). Due to the nature of overeating, three factors are distinguished, each of which contains 10 questions: habit overeating (0-10 points), emotional overeating ( $0-10$ points), and the tendency to restrain from eating ( $0-10$ points). This tool enables the diagnosis of eating disorders, predicts the tendency for being overweight, and is used in the selection of interventions, the aim of which is to reduce excessive body weight [26].

Wellbeing was measured using the Psychosocial Working Conditions (originally PWP) (Cronbach's alpha of 0.90) questionnaire and two factors related to physical and mental dimensions, which are collectively referred to as mental and physical conditions. The D1 scale consists of a general assessment of physical health and stress, as well as the occurrence of somatic symptoms, such as headaches and stomach and heart problems. Factors concerning mental wellbeing (D2) focus on the assessment of negative emotional states, life and job satisfaction, and self-confidence. High values reflect a higher level of wellbeing. The questionnaire contains standards developed for eight professional groups, including nurses. The results can be expressed as a sten score, where results in the range 1-4 mean low wellbeing, those in the range 5-6 mean average wellbeing, and those in the range 7-10 mean high wellbeing [27]. Lastly, we used the Assessment of Resiliency Scale (SPP-25) by Ogińska-Bulik and Juczyński (Cronbach's alpha of 0.89) [28] to measure the overall level of resilience among the nurses. The scale measures the five constituting factors of resilience: (1) determination and persistence in action, (2) openness to new experiences and a sense of humour, (3) personal competencies to cope and tolerance of negative effects, (4) tolerance of failures and treating life as a challenge, and (5) an optimistic life attitude and ability to mobilise in difficult situations. These five characteristics are rated on a five-point Likert scale (from 0 -strongly disagree to 4 -strongly agree). The overall score on the SPP-25 is the sum of the five aforementioned factors (i.e., five points per item). A higher score denotes a higher level of resilience. The overall result of SPP- 25 can be expressed on a sten scale, in which the results ranging from 1 to 4 mean low resilience, those ranging from 5-6 mean average resilience, and those ranging from 7-10 mean high resilience [28]. Improperly completed questionnaires were excluded from the analysis.

\subsection{Statistical Analysis}

As far as quantitative variables are concerned, the Mann-Whitney $U$ test was used to assess differences between the two groups. The chi-squared test of independence was used to assess dependencies between variables in the nominal and ordinal scale. Some risk factors were compared using the Kruskal-Wallis analysis of variance (ANOVA) test or a oneway ANOVA. Spearman's correlation coefficients were used to evaluate the correlations between quantitative variables. All statistic tests were calculated at the significance level alpha $\leq 0.05$ and performed using SPSS and Statistica software.

\section{Results}

\subsection{Characteristics of Studied Group}

In total, 1200 participants met the inclusion criteria and were provided with the survey in an envelope. Of them, 1080 returned the completed survey (i.e., a response rate of $90 \%$ ). The nurses subject to the analysis were aged 24-63 years (the mean age was 42.8 years). Nearly half $(44 \%)$ had worked in their profession for over 20 years $(n=484)$, and almost $40 \%(n=397)$ held additional employment. Overall, $379(35 \%)$ nurses consumed alcohol in a harmful way, and $\sim 20 \%$ were smokers.

The general characteristics of the study group are summarised in Table 1. 
Table 1. General characteristics of the analysed group of nurses in Poland.

\begin{tabular}{|c|c|}
\hline Characteristic & $N(\%)$ \\
\hline \multicolumn{2}{|l|}{ Sex } \\
\hline Male & $28(2.6 \%)$ \\
\hline Female & $1052(97.4 \%)$ \\
\hline \multicolumn{2}{|l|}{ Age (years) } \\
\hline$\leq 30$ & $132(12.3 \%)$ \\
\hline $31-40$ & $208(19.2 \%)$ \\
\hline $41-50$ & $587(54.3 \%)$ \\
\hline$\geq 51$ & $153(14.2 \%)$ \\
\hline \multicolumn{2}{|l|}{ Marital status } \\
\hline Single & $760(71.1 \%)$ \\
\hline Married & $105(9.8 \%)$ \\
\hline Divorced & $178(16.7 \%)$ \\
\hline Widowed & $26(2.4 \%)$ \\
\hline \multicolumn{2}{|l|}{ Additional employment } \\
\hline Yes & $397(36.8 \%)$ \\
\hline No & $638(63.2 \%)$ \\
\hline \multicolumn{2}{|l|}{ Type of ward } \\
\hline Surgical & $354(32.7 \%)$ \\
\hline Nonsurgical & $726(67.3 \%)$ \\
\hline \multicolumn{2}{|l|}{ Attitude to smoking ${ }^{\dagger}$} \\
\hline Smoker & $214(19.8 \%)$ \\
\hline Ex-smoker & $182(16.9 \%)$ \\
\hline Non-smoker & $684(63.3 \%)$ \\
\hline \multicolumn{2}{|l|}{ Alcohol consumption $\ddagger$} \\
\hline Risk of alcohol addiction & $378(35 \%)$ \\
\hline No risk of alcohol addiction & $702(65 \%)$ \\
\hline \multicolumn{2}{|l|}{ Psychophysical mood II } \\
\hline High & $166(15.4 \%)$ \\
\hline Average & $735(68 \%)$ \\
\hline \multirow[t]{2}{*}{ Low } & $179(16.6 \%)$ \\
\hline & M (SD) \\
\hline Psychophysical mood & $3.56(0.51)$ \\
\hline Physical wellbeing (D1) & $3.68(0.59)$ \\
\hline Mental mood (D2) & $3.45(0.53)$ \\
\hline \multicolumn{2}{|l|}{ Resiliency ": } \\
\hline High & $176(16.3 \%)$ \\
\hline Average & $649(60.1 \%)$ \\
\hline \multirow[t]{2}{*}{ Low } & $255(23.6 \%)$ \\
\hline & M (SD) \\
\hline
\end{tabular}


Table 1. Cont.

\begin{tabular}{lc}
\hline \multicolumn{1}{c}{ Characteristic } & N (\%) \\
\hline Determination and persistence in action & $14.26(3.23)$ \\
\hline Openness to new experiences and a sense of humour & $13.87(3.13)$ \\
\hline Personal competencies to cope and tolerance of negative effect & $13.40(3.40)$ \\
\hline Tolerance of failures and treating life as a challenge & $13.89(3.76)$ \\
\hline Optimistic life attitude and ability to mobilise in difficult situations & $12.87(3.33)$ \\
\hline Eating habits & $\$$ \\
\hline Eating habits-total & M (SD) \\
\hline Restraint from eating & $10.65(5.96)$ \\
\hline Emotional overeating & $3.56(2.24)$ \\
\hline Habit overeating & $4.10(2.59)$ \\
\hline
\end{tabular}

${ }^{\dagger}$ Based on the Fagerström test for nicotine dependence. ${ }^{\ddagger}$ Based on the Alcohol Use Disorders Identification Test for Consumption (AUDIT-C) screening test for risk of alcohol abuse. II Based on the Psychosocial Working Conditions (PWP) questionnaire. ": Based on the Assessment of Resiliency Scale (SPP-25). ${ }^{\S}$ Based on My Eating Habits (MEH) questionnaire. Note: Any questionnaires that were completed incorrectly were excluded from the analysis; therefore, numbers may not add up to 1080 . M, mean.

\subsection{Psychophysical Wellbeing}

The mental and physical condition of the group of nurses under analysis was determined with the use of the wellbeing scale (D) of the Psychosocial Working Conditions questionnaire [27]. The overriding question in the theoretical scale (D) was the following: "How do you feel?" The D1 scale involves an overall assessment of physical health and stress and the occurrence of somatic symptoms, such as headaches and stomach and heart problems. The mental wellbeing (D2) scale focuses on the assessment of negative emotional states, life and job satisfaction, and self-confidence.

Over half of nurses $(n=735 ; 68 \%)$ had an average psychophysical mood according to the PWP scale, and 179 (16.6\%) had low mood levels (Table 1).

Widows or widowers were found to have a lower psychophysical mood (mean [standard deviation] score of 3.31 [0.64] on the PWP scale) than married nurses (3.58 [0.52]) or those who were single (3.61 [0.48]; $\mathrm{F}=-3.035 ; p=0.028$; one-way ANOVA). Moreover, nurses who were additionally employment had a better sense of wellbeing (mean score of 3.62 [0.52]) than those without additional employment (mean score of 3.54 [0.52]; $\mathrm{Z}=-2.395 ; p=0.017$; Mann-Whitney $\mathrm{U}$ test; Table 2).

Table 2. Characteristics of the studied group of nurses, including psychophysical wellbeing and sociodemographic features.

\begin{tabular}{|c|c|c|c|c|c|}
\hline \multirow{3}{*}{ Wellbeing Scale \# } & \multicolumn{5}{|c|}{ Age (Years) } \\
\hline & $\leq \mathbf{3 0}$ & $31-40$ & $41-50$ & $\geq 51$ & Kruskal-Wallis ANOVA \\
\hline & M (SD) & M (SD) & M (SD) & M (SD) & $p$-Value \\
\hline Psychophysical mood & $3.59(0.46)$ & $3.62(0.58)$ & $3.54(0.50)$ & $3.56(0.51)$ & 0.302 \\
\hline Physical wellbeing (D1) & $3.74(0.55)$ & $3.72(0.64)$ & $3.66(0.59)$ & $3.68(0.57)$ & 0.210 \\
\hline Mental mood (D2) & $3.43(0.47)$ & $3.51(0.60)$ & $3.43(0.52)$ & $3.44(0.55)$ & 0.161 \\
\hline
\end{tabular}


Table 2. Cont.

\begin{tabular}{|c|c|c|c|c|c|c|}
\hline & \multicolumn{6}{|c|}{ Marital Status } \\
\hline & Single & Married & Divorced & Widowed & \multicolumn{2}{|c|}{ (One-Way ANOVA) } \\
\hline & M (SD) & M (SD) & M (SD) & M (SD) & \multicolumn{2}{|c|}{$p$-Value } \\
\hline Psychophysical mood & $3.61(0.48)$ & $3.58(0.52)$ & $3.52(0.56)$ & $3.31(0.64)$ & \multicolumn{2}{|c|}{0.028} \\
\hline Physical wellbeing (D1) & $3.77(0.55)$ & $3.69(0.59)$ & $3.67(0.60)$ & $3.35(0.87)$ & \multicolumn{2}{|c|}{0.009} \\
\hline \multirow[t]{4}{*}{ Mental mood (D2) } & $3.46(0.51)$ & $3.47(0.53)$ & $3.37(0.61)$ & $3.26(0.59)$ & & \\
\hline & \multicolumn{6}{|c|}{ Additional employment } \\
\hline & \multicolumn{2}{|c|}{ Yes } & \multicolumn{2}{|c|}{ No } & \multicolumn{2}{|c|}{ (Mann-Whitney U Test) } \\
\hline & \multicolumn{2}{|c|}{$\mathrm{M}(\mathrm{SD})$} & \multicolumn{2}{|c|}{ M (SD) } & $Z$ & $p$-value \\
\hline Psychophysical mood & \multicolumn{2}{|c|}{$3.62(0.52)$} & \multicolumn{2}{|c|}{$3.54(0.52)$} & -2.395 & 0.017 \\
\hline Physical wellbeing (D1) & \multicolumn{2}{|c|}{$3.74(0.58)$} & \multicolumn{2}{|c|}{$3.66(0.59)$} & -2.062 & 0.039 \\
\hline \multirow[t]{4}{*}{ Mental mood (D2) } & \multicolumn{2}{|c|}{$3.50(0.59)$} & \multicolumn{2}{|c|}{$3.42(0.53)$} & -2.475 & 0.013 \\
\hline & \multicolumn{6}{|c|}{ Type of ward } \\
\hline & \multicolumn{2}{|c|}{ Surgical } & \multicolumn{2}{|c|}{ Non-surgical } & \multicolumn{2}{|c|}{ (Mann-Whitney U Test) } \\
\hline & \multicolumn{2}{|c|}{ M (SD) } & \multicolumn{2}{|c|}{ M (SD) } & $Z$ & $p$-value \\
\hline Psychophysical mood & \multicolumn{2}{|c|}{$3.58(0.52)$} & \multicolumn{2}{|c|}{$3.56(0.52)$} & -0.571 & 0.568 \\
\hline Physical wellbeing (D1) & \multicolumn{2}{|c|}{$3.71(0.59)$} & \multicolumn{2}{|c|}{$3.68(0.59)$} & -0.727 & 0.467 \\
\hline Mental mood (D2) & \multicolumn{2}{|c|}{$3.46(0.52)$} & \multicolumn{2}{|c|}{$3.44(0.54)$} & -0.301 & 0.763 \\
\hline
\end{tabular}

Abbreviation: $M(S D)$, mean (standard deviation). " Based on the Psychosocial Working Conditions (PWP) questionnaire.

The correlations between psychophysical wellbeing and nicotine dependence, alcohol consumption, and eating habits are presented in Table 3.

Table 3. Correlations between the wellbeing of Polish nurses and their smoking, drinking, and eating habits.

\begin{tabular}{cccc}
\hline \multirow{2}{*}{ Parameter } & Psychophysical Mood & $\begin{array}{c}\text { Physical } \\
\text { Wellbeing (D1) }\end{array}$ & Mental Mood (D2) \\
\cline { 2 - 4 } & $r(p$-Value) & $r(p$-Value) & $r(p$-Value) \\
\hline Fagerström test for nicotine $^{\dagger}$ & $-0.079(0.010)$ & $-0.074(0.015)$ & $-0.073(0.017)$ \\
\hline AUDIT-C test ${ }^{\ddagger}$ & $-0.096(0.002)$ & $-0.080(0.009)$ & $-0.096(0.002)$ \\
\hline Eating habits-total $^{\#}$ & $-0.234(<0.001)$ & $-0.209(<0.001)$ & $-0.220(<0.001)$ \\
\hline Restraint from eating $^{\#}$ & $-0.126(<0.001)$ & $-0.123(<0.001)$ & $-0.105(<0.001)$ \\
\hline Emotional overeating $^{\#}$ & $-0.232(<0.001)$ & $-0.206(0.001)$ & $-0.219(<0.001)$ \\
\hline Habit overeating ${ }^{\#}$ & $-0.161(<0.001)$ & $-0.130(<0.001)$ & $-0.168(<0.001)$ \\
\hline
\end{tabular}

Abbreviation: $r$, Spearman's coefficients of rank correlation. ${ }^{\dagger}$ Based on the Fagerström test for nicotine dependence. ${ }^{\ddagger}$ Based on the AUDIT-C screening test for risk of alcohol abuse. \# Based on My Eating Habits (MEH) questionnaire.

\subsection{Resilience}

We used the SPP-25 scale to evaluate nurses' mental resilience [28].

Nurses with an average level of resilience predominated $(n=649 ; 60.1 \%)$, followed by those with low $(n=255 ; 23.6 \%)$ and high resilience levels $(n=176 ; 16.3 \%)$.

Younger nurses ( $<31$ years of age) had lower resilience scores than those aged over 30 years old ( $p=0.004$, Kruskal-Wallis ANOVA). Nurses with additional employment displayed higher levels of resilience (mean score of 69.46 [14.49]) than individuals without additional employment (mean score of 67.46 [15.01]; $Z=-2.656 ; p=0.008$; Mann-Whitney U test; Table 4). 
Table 4. Relationships between resilience and the sociodemographic characteristics of Polish nurses.

\begin{tabular}{|c|c|c|c|c|c|c|}
\hline \multirow{3}{*}{ Parameter } & & \multicolumn{5}{|c|}{ Factors } \\
\hline & Resiliency-Total & 1 & 2 & 3 & 4 & 5 \\
\hline & M (SD) & M (SD) & M (SD) & M (SD) & M (SD) & M (SD) \\
\hline \multicolumn{7}{|c|}{ Age (years) } \\
\hline$\leq 30$ & $64.67(14.37)$ & $13.51(3.38)$ & $13.31(3.15)$ & $12.70(3.25)$ & $13.03(3.14)$ & $12.12(3.16)$ \\
\hline $31-40$ & $69.54(14.54)$ & $14.53(3.04)$ & $14.28(3.11)$ & $13.62(3.34)$ & $14.07(3.11)$ & $13.04(3.36)$ \\
\hline $41-50$ & $68.37(14.70)$ & $14.29(3.13)$ & 13.85 (3.07) & $13.44(3.37)$ & $13.88(3.25)$ & $12.91(3.29)$ \\
\hline$\geq 51$ & $68.72(15.88)$ & $14.29(3.15)$ & $13.86(3.33)$ & $13.56(3.68)$ & $13.92(3.59)$ & $13.08(3.56)$ \\
\hline $\begin{array}{c}p \text {-Value } \\
\text { (Kruskal-Wallis } \\
\text { ANOVA) }\end{array}$ & 0.004 & 0.017 & 0.024 & 0.017 & 0.011 & 0.016 \\
\hline \multicolumn{7}{|c|}{ Marital status } \\
\hline Single & $67.52(14.99)$ & $13.99(3.23)$ & 13.99 (3.09) & $13.26(3.32)$ & $13.63(3.30)$ & $12.64(3.42)$ \\
\hline Married & $68.66(14.50)$ & $14.35(3.13)$ & $13.91(3.07)$ & $13.50(3.33)$ & $13.90(3.21)$ & $12.99(3.21)$ \\
\hline Divorced & $68.06(15.68)$ & $14.42(2.86)$ & $13.71(3.28)$ & $13.32(3.82)$ & $13.90(3.54)$ & $12.70(3.71)$ \\
\hline Widowed & $63.27(19.88)$ & $12.77(4.38)$ & $12.85(4.26)$ & $12.85(4.14)$ & $12.88(3.94)$ & $11.92(4.59)$ \\
\hline $\begin{array}{c}p \text {-Value } \\
\text { (One-way ANOVA) }\end{array}$ & 0.268 & 0.048 & 0.328 & 0.656 & 0.355 & 0.236 \\
\hline \multicolumn{7}{|c|}{ Additional employment } \\
\hline Yes & $69.46(14.49)$ & $14.38(3.11)$ & $14.03(3.11)$ & $13.84(3.38)$ & $14.11(3.22)$ & $13.11(3.16)$ \\
\hline No & $67.46(15.01)$ & $14.16(3.19)$ & 13.78 (3.15) & $13.14(3.39)$ & $13.65(3.29)$ & $12.73(3.43)$ \\
\hline $\begin{array}{c}p \text {-Value } \\
\text { (Mann-Whitney } \\
\text { U Test) }\end{array}$ & 0.008 & 0.109 & 0.157 & 0.01 & 0.015 & 0.048 \\
\hline Z & -2.656 & -1.604 & -1.416 & 3.954 & -2.423 & -1.975 \\
\hline \multicolumn{7}{|c|}{ Type of ward } \\
\hline Surgical & 67.65 (14.47) & 14.07 (3.15) & $13.76(3.11)$ & $13.25(3.34)$ & $13.84(3.89)$ & $12.84(3.23)$ \\
\hline Non-surgical & $68.46(15.03)$ & $14.35(3.26)$ & $13.92(3.15)$ & $13.47(3.43)$ & $13.92(3.70)$ & $12.88(3.39)$ \\
\hline $\begin{array}{c}p \text {-Value } \\
\text { (Mann-Whitney } \\
\text { U Test) }\end{array}$ & 0.205 & 0.202 & 0.287 & 0.167 & 0.287 & 0.843 \\
\hline$Z$ & -1.268 & -1.276 & -1.066 & -1.382 & -1.065 & -0.198 \\
\hline
\end{tabular}

Abbreviation: $M(S D)$, mean (standard deviation). *: Based on the Assessment of Resiliency Scale (SPP-25). 1. Determination and persistence in action. 2. Openness to new experiences and a sense of humour. 3. Personal competencies to cope and tolerance of negative effect. 4. Tolerance of failures and treating life as a challenge. 5. Optimistic life attitude and ability to mobilise in difficult situations.

Nurses with high levels of resilience had a significantly better psychophysical mood (mean score of 3.80 [0.53] on the PWP scale) than those with low (mean score of 3.28 [0.53]) and average (mean score of 3.62 [0.46]) levels of resilience ( $p<0.01$; Kruskal-Wallis ANOVA).

Nurses with high resilience had a significantly lower risk of alcohol addiction $(p=0.003$; chi-square test) and better eating habits (overall score on the MEH scale; $p=0.001$; KruskalWallis ANOVA) than individuals with average and low resilience levels (Table 5). 
Table 5. Comparison of resilience among various forms of risky behaviour and wellbeing.

\begin{tabular}{|c|c|c|c|c|}
\hline Parameter & $\begin{array}{c}\text { Resiliency } \\
\text { Low }^{\#} \\
(n=255) \\
N(\%)\end{array}$ & $\begin{array}{c}\text { Resiliency } \\
\text { Average } \\
(n=649) \\
N(\%)\end{array}$ & $\begin{array}{c}\text { Resiliency } \\
\text { High } \# \\
(n=176) \\
N(\%)\end{array}$ & $\begin{array}{c}p \text {-Value } \\
\text { (Chi-Squared Test) }\end{array}$ \\
\hline Attitude to smoking & & & & 0.711 \\
\hline Smokers & $39(15.3 \%)$ & $109(16.8 \%)$ & $32(18.13 \%)$ & \\
\hline Non-smokers & $216(84.7 \%)$ & $540(83.2 \%)$ & $143(81.7 \%)$ & \\
\hline Alcohol consumption ${ }^{\dagger}$ & & & & 0.003 \\
\hline Risk of alcohol addiction & $95(37.3 \%)$ & $241(37.1 \%)$ & $42(23.9 \%)$ & \\
\hline \multirow[t]{2}{*}{ No risk of alcohol addiction } & $160(62.7 \%)$ & $408(62.9 \%)$ & $134(76.1 \%)$ & \\
\hline & M (SD) & M (SD) & M (SD) & $\begin{array}{c}p \text {-value } \\
\text { (Kruskal-Wallis ANOVA) }\end{array}$ \\
\hline \multicolumn{5}{|l|}{ Wellbeing II } \\
\hline Psychophysical mood & $3.28(0.53)$ & $3.62(0.46)$ & $3.80(0.53)$ & $<0.001$ \\
\hline Physical wellbeing & $3.46(0.58)$ & $3.73(0.56)$ & $3.85(0.64)$ & $<0.001$ \\
\hline Mental mood & $3.11(0.56)$ & $3.51(0.46)$ & $3.74(0.52)$ & $<0.001$ \\
\hline \multicolumn{5}{|l|}{ Eating habits $\S$} \\
\hline Eating habits-total & $12.01(6.68)$ & $10.35(5.66)$ & $9.80(5.62)$ & 0.001 \\
\hline Restraint from eating & $3.56(2.25)$ & $3.59(2.25)$ & $3.42(2.22)$ & 0.711 \\
\hline Emotional overeating & $4.64(2.86)$ & $3.97(2.47)$ & $3.79(2.54)$ & 0.002 \\
\hline Habit overeating & $3.80(2.96)$ & $2.79(2.47)$ & $2.59(2.36)$ & $<0.001$ \\
\hline
\end{tabular}

Abbreviation: $M(S D)$, mean (standard deviation). ${ }^{*}$ Based on the Assessment of Resiliency Scale (SPP-25). ${ }^{+}$Based on the AUDIT-C screening test. ${ }^{\mathbb{I}}$ Based on the Psychosocial Working Conditions (PWP) questionnaire. ${ }^{\S}$ Based on My Eating Habits (MEH) questionnaire. Note: Any questionnaires that were completed incorrectly were excluded from the analysis; therefore, numbers may not add up to 1080.

\section{Discussion}

Several studies have shown that nurses are burdened with job-related stress [29-33]. In this study, we determined the effects on the health of nurses using the wellbeing scale (D) of the PWP questionnaire [27], which enables an assessment of their physical and mental mood. We found over half of the nurses in this study had an average psychophysical mood and 17\% had low mood levels (note: participants scored higher on the physical wellbeing scale than on the mental mood scale). Our findings reflect those reported among nurses working in another region of Poland who had similar mean scores obtained on all scales of the PWP questionnaire $[34,35]$. Previous multicentre studies have found common prognostic factors affecting psychophysical mood including age, job satisfaction, sleeping disorders, years of employment, and marital status [34-38]. We found that psychophysical mood was also influenced by marital status, as well as additional employment (i.e., nurses who took on additional employment had better wellbeing), which suggests that wellbeing may impact nurses' willingness to work. This finding concurs with studies conducted in 2002-2005 with the international research programme called the NEXT Study (Nurses' Early Exit Study) aimed at identifying the reasons why nurses leave the profession. In particular, measures of mental wellbeing were strongly related to the intention of "leaving" a job and may largely determine the actual decision to resign [39].

Stress and the inability to cope can have a negative impact on employees' wellbeing, thus leading to burnout and/or the development of various diseases [6,40,41]. Moreover, high levels of stress can result in or aggravate non-adaptation behaviours, such as smoking, overeating/undereating [42,43], excessive alcohol consumption, and substance abuse. However, we found that nurses' psychophysical mood was only weakly correlated $(r<0.2$; $p=0.001$ ) with smoking (assessed using the Fagerström test for nicotine dependence) and 
risky alcohol consumption (as evaluated by AUDIT-C). A slightly higher result ( $r=-0.23$; $p=0.001$ ) was observed between psychophysical mood and scores on the My Eating Habits questionnaire, indicating that nurses with low psychophysical mood may have a greater tendency to have improper eating habits.

The mechanism of self-regulation, protecting nurses against the negative consequences of experiencing both traumatic and everyday events, consists of resilience [44]. We found that Polish nurses experienced average levels of resilience, which is in line with many national and international studies $[13,17,45,46]$, as well as people working in the Polish normalisation group [28]. As in the previous studies among nurses [17,47,48], we found that younger nurses ( $<30$ years) had lower resilience than older nurses. The findings indicate that there is a great need for healthcare organisations and nursing leaders to develop programmes that focus on building better resilience among younger and less experienced nurses. Furthermore, we demonstrated that nurses with additional employment displayed higher levels of resilience than those who did not take up additional employment. This finding supports previous research suggesting that individuals with higher resilience are more open to new experiences and engage in relationships at greater levels [49]. We also found that nurses with a high resilience level had a significantly better psychophysical mood (reflecting the perceived stress level) than those with low and average resilience, as observed in earlier studies [44,50,51]. Resilience is also treated as an important resource that protects against professional burnout [52] and the development of post-traumatic stress disorder (PTSD) symptoms [53]. Moreover, the lowest number of nurses consuming alcohol in a harmful way was found among individuals possessing high levels of resilience. These results are consistent with those of other studies concerning alcohol addiction, i.e., those who consume alcohol in harmful ways display lower resilience levels than the general population [54]. Similarly, as previously shown, non-smoking nurses in China had significantly higher resilience levels than those who smoked [46]. We also found that nurses with high resilience had better eating habits, which is in line with other reports that show people with compulsive overeating habits have low levels of resilience [55]. Likewise, a study conducted among young people showed that high resilience was a protective factor against risky forms of behaviour, such as smoking, alcohol consumption, and taking drugs [56].

As regards the conducted studies, personality resilience should be regarded as a significant factor influencing some aspects of lifestyle among Polish nurses. Therefore, the authors aim to present the results of their studies to nursing managers and to representatives of teaching hospitals. The aforementioned results will form the basis for the preparation of educational programmes. Considering the increasing demand for care and ageing of nursing personnel, we must consider the implementation of strategies aimed at the improvement of their psychophysical mood. Taking the above into consideration, workplace managers should implement strategies aimed at evaluating the psychophysical mood and mental resilience of personnel, e.g., via the application of screening questionnaires that can identify at-risk personnel. The suggested evaluation could be applied, for example, during periodic medical examinations undertaken in the workplace. It is important for employers to take care not only of the physical health of their employees but also their mental health. It would be advisable to offer psychological assistance to those personnel who require it. The conducted research indicates that an evaluation of mental resilience should be created particularly for younger or less experienced nurses. Resilience as an inborn energy or vital force may enhance the position of nurses by positively adjusting them to stressful situations and may apply their experiences as a learning process [57]. Resilience may enhance the ability of nurses to effectively cope with stress (thanks to a better psychophysical mood), as well as reduce unhealthy forms of behaviour (habitual or emotional overeating, the application of dietary restrictions, and the consumption of alcohol in a risky way). Relatedly, hospital administrators and managers of nursing departments should realise the importance of mental resilience and regularly evaluate the issue of nurses' mental health. The need for continuous supervision over the preparation of 
nurses to perform their professional duties was also mentioned in another Polish study [58]. What seems to be advisable as well is the institution of coherent measurement tools which could allow researchers to compare diverse research results aiming at drawing the relevant conclusions related to the improvement of nurses' resilience. It seems that the tools used in the study properly reviewed the areas considered.

Our study had some limitations. The data collected in the study were based on voluntary questionnaires carried out in one region of Poland. Therefore, the findings may not reflect all nurses working in all regions of Poland. However, we provided a large cohort, which ensures that the data are somewhat representative of the national population of nurses in Poland. Self-descriptive measurement tools were used in the studies, which are associated with the possibility of the occurrence of a variable social approval, i.e., the will of respondents to be presented in a better light. Moreover, the studies were cross-sectional. Subsequently, it was not possible to unequivocally formulate cause-and-effect relations on their basis.

\section{Conclusions}

A significant percentage of nurses in Poland manifested average and low mental resilience. This was associated with unhealthy lifestyle behaviour and deteriorating mental and physical condition, which could adversely affect their professional performance and increase the risk of chronic diseases. Particular attention should also be paid to younger nurses who show lower mental resilience, which, in the absence of any intervention, may result in the deterioration of one's mental and physical condition and the occurrence of risky behaviour. Moreover, both mental resilience and good physical condition were associated with additional employment. Therefore, taking into account mental factors such as personality resilience in preventive examinations will improve the professional performance of nurses.

Author Contributions: Conceptualisation, L.G.-W., J.D. and H.K.; formal analysis, H.K.; methodology, L.G.-W. and H.K.; writing — original draft, L.G.-W.; writing—review and editing, L.G.-W. and J.D. All authors have read and agreed to the published version of the manuscript.

Funding: This research received no external funding.

Institutional Review Board Statement: The study was conducted according to the guidelines of the Declaration of Helsinki, and approved by the Ethics Committee of Silesian Medical University in Katowice approved the study (KNW 0022/KB/89/1/17; 30 May 2017).

Informed Consent Statement: Informed consent was obtained from all subjects involved in the study. Data Availability Statement: Not applicable.

Conflicts of Interest: The authors declare no conflict of interest.

\section{References}

1. Buchan, J.; Duffield, C.; Jordan, A. 'Solving' nursing shortage: Do we need a New Agenda? J. Nurs. Manag. 2015, 23, 543-545. [CrossRef]

2. Cope, V.; Jones, B.; Hendricks, J. Why nurses chose to remain in the workforce: Portraits of resilience. Collegian 2016, 23, 87-95. [CrossRef]

3. Gascon, S.; Leiter, M.P.; Andres, E.; Santed, M.A.; Pereira, J.P.; Cunha, M.J.; Albesa, A.; Montero-Marín, J.; García-Campayo, J.; Martínez-Jarreta, B. The role of aggressions suffered by healthcare workers as predictors of burnout. J. Clin. Nurs. 2013, 22, 3120-3129. [CrossRef]

4. Van Bogaert, P.; Adriaenssens, J.; Dilles, T.; Martens, D.; Van Rompaey, B.; Timmermans, O. Impact of role-, job and organizational characteristics on nursing unit managers' work related stress and well-being. J. Adv. Nurs. 2014, 70, 2622-2633. [CrossRef]

5. Hayes, B.; Douglas, C.; Bonner, A. Work environment, job satisfaction, stress and burnout among haemodialysis nurses. J. Nurs. Manag. 2015, 23, 588-598. [CrossRef] [PubMed]

6. Dębska, G.; Pasek, M.; Wilczek-Rużyczka, E. Obciażenia psychiczne i wypalenie zawodowe u pielęgniarek u pielegniarek pracujących w różnych specjalnościach zawodowych. Hygeia Public Health 2014, 49, 113-119.

7. Bejer, A.; Bieniek, R. Stress at work and in everyday life and the occurrence of cardiovascular disease. Med. Rev. 2016, 14, 401-415. [CrossRef] 
8. Perry, L.; Xu, X.; Gallagher, R.; Nicholls, R.; Sibbritt, D.; Duffield, C. Lifestyle health behaviors of nurses and midwives: The 'Fit for the Future' Study. Int J. Environ. Res. Public Health 2018, 15, 945. [CrossRef]

9. Junqueira, M.A.B.; Ferreira, M.C.M.; Soares, G.T.; Brito, I.E.; Pires, P.L.S.; Santos, M.A.D.; Pillon, S.C. Alcohol use and health behavior among nursing professionals. Rev. Esc. Enferm. USP 2017, 51, e03265. [CrossRef]

10. Kyle, R.G.; Neall, R.A.; Atherton, I.M. Prevalence of overweight and obesity among nurses in Scotland: A cross-sectional study using the Scottish Health Survey. Int. J. Nurs. Stud. 2016, 53, 126-133. [CrossRef]

11. Owusu-Sekyere, F. Assessing the effect of physical activity and exercise on nurses' well-being. Nurs. Standard 2020, 35, 45-50. [CrossRef] [PubMed]

12. Perry, L.; Gallagher, R.; Duffield, C. The health and health behaviours of Australian metropolitan nurses: An exploratory study. BMC Nurs. 2015, 14, 45. [CrossRef]

13. Rushton, C.H.; Batcheller, J.; Schroeder, K.; Donohue, P. Burnout and resilience among nurses practicing in high-intensity settings. Am. J. Crit. Care 2015, 24, 412-420. [CrossRef]

14. Kaczmarek, Ł.; Sęk, H.; Ziarko, M. Sprężystość psychiczna i zmienne pośredniczące w jej wpływie na zdrowie. Prz. Psychol. 2011, $54,29-46$.

15. Kasprzak, A.; Basińska, M.A.; Lewandowska, P.N. Resiliency and the subjective evaluation of health in mothers of children with Asperger's syndrome. Health Psychol. Rep. 2013, 1, 34-41. [CrossRef]

16. Fredrickson, B. The role of positive emotions in positive psychology: The broaden-and-bulid theory of positive emotions. Am. Psychol. 2001, 63, 923-931. [CrossRef]

17. Mróz, J. Znaczenie zasobów osobistych dla zachowań i przeżyć związanych z praca pielegniarek. Probl. Hig. Epidemiol. 2014, 95, 731-736.

18. Bonanno, G.A. Loss, Trauma, and Human Resilience: Have We Underestimated the Human Capacity to Thrive After Extremely Aversive Events? Am. Psychol. 2004, 59, 20-28. [CrossRef] [PubMed]

19. Bryl, N.; Czarnecka-Iwańczuk, M.; Romanowska, M.; Stanišić, M.-G.; Michalak, M.; Posadzy-Małaczyńska, A. Drinking alcohol as a way of coping with stress in studentsof medical faculties. Psychiatr. Pol. 2020, 54, 265-277. [CrossRef] [PubMed]

20. Lazarus, R.S. Coping theory and research: Past, present and future. Psychosom Med. 1993, 55, 234-247. [CrossRef] [PubMed]

21. Bush, K.; Kivlahan, D.R.; McDonell, M.B.; Fihn, S.D.; Bradley, K.A. The AUDIT alcohol consumption questions (AUDIT-C): An effective brief screening test for problem drinking. Ambulatory Care Quality Improvement Project (ACQUIP). Alcohol Use Disorders Identification Test. Arch. Intern. Med. 1998, 158, 1789-1795. [CrossRef]

22. Bradley, K.A.; Bush, K.R.; Epler, A.J.; Dobie, D.J.; Davis, T.M.; Sporleder, J.L.; Kivlahan, D.R. Two brief alcohol-screening tests from the alcohol use disorders identification test (AUDIT): Validation in a female Veterans Affairs patient population. Arch. Intern. Med. 2003, 163, 821-829. [CrossRef]

23. Bradley, K.A.; DeBenedetti, A.F.; Volk, R.J.; Williams, E.C.; Frank, D.; Kivlahan, D.R. AUDIT-C as a brief screen for alcohol misuse in primary care. Alcohol. Clin. Exp. Res. 2007, 31, 1208-1217. [CrossRef]

24. Heatherton, T.F.; Kozlowski, L.T.; Frecker, R.C.; Fagerstrom, K.O. The Fagerstrom Test for Nicotine Dependence: A revision of the Fagerstrom Tolerance Questionnaire. Br. J. Addict. 1991, 86, 1119-1127. [CrossRef] [PubMed]

25. Samochowiec, J.; Rogoziński, D.; Hajduk, A.; Skrzypińska, A.; Arentowicz, A. The Diagnostics, Mechanism of Dependence and Nicotine Dependence Treatment. Alkohol. Narkom. 2001, 14, 323-340.

26. Ogińska-Bulik, N.; Putyński, L. Kwestionariusz Moje Zwyczaje Żywieniowe-konstrukcja i właściwości psychometryczne. Acta Univ. Lodziensis. Folia Psychol. 2000, 4, 25-31.

27. Cieślak, R.; Widerszal-Bazyl, M. Psychospołeczne Warunki Pracy. Podręcznik do Kwestionariusza; Centralny Instytut Ochrony Pracy: Warszawa, Poland, 2000.

28. Ogińska-Bulik, N.; Juczyński, Z. Skala pomiaru prężności-SPP-25. Now. Psychol. 2008, 3, 39-56.

29. Pietraszek, A.; Charzyńska-Gula, M.; Łuczyk, M.; Szadowska-Szlachetka, Z.; Kachaniuk, H.; Kwiatkowska, J. Analiza przyczyn stresu zawodowego w opinii pielegniarek. J. Educ. Health Sport 2016, 6, 643-652, eISSN 2391-8306. [CrossRef]

30. Kath, L.M.; Stichler, J.F.; Ehrhart, M.G.; Sievers, A. Predictors of Nurse Manager Stress: A Dominance Analysis of Potential Work Environment Stressors. Int J. Nurs. Stud. 2013, 50, 1474-1480. [CrossRef]

31. Udod, S.A.; Care, W.D. Nurse managers' work stressors and coping experiences: Unravelling the evidence. Nurs. Leadersh (Tor Ont) 2011, 24, 57-72. [CrossRef] [PubMed]

32. Warshawsky, N.E.; Havens, D.S. Nurse manager job satisfaction and intent to leave. Nurs. Econ. 2014, 32, 32-39. [PubMed]

33. Maharaj, S.; Lees, T.; Lal, S. Prevalence and Risk Factors of Depression, Anxiety, and Stress in a Cohort of Australian Nurses. Int. J. Environ. Res. Public Health 2018, 16, 61. [CrossRef] [PubMed]

34. Kowalczuk, K.; Krajewska-Kułak, E.; Rolka, H.; Kondzior, D.; Sarnacka, E. Psychospołeczne warunki pracy pielegniarek. Hygeia Public Health 2015, 50, 621-629.

35. Kowalczuk, K.; Krajewska-Kułak, E. Influence of selected sociodemogrphic factors on psychosocial workload of nurses. Med. Pr. 2015, 66, 615-624. [CrossRef] [PubMed]

36. Ardekani, Z.Z.; Kakooei, H.; Ayattollahi, S.M.; Choobineh, A.; Seraji, G.N. Prevalence of mental disorders among shift work hospital nurses in Shiraz, Iran. Pak. J. Biol. Sci. 2008, 11, 1605-1609. [CrossRef]

37. Cheung, T.; Yip, P.S.F. Depression, Anxiety and Symptoms of Stress among Hong Kong Nurses: A Cross-sectional Study. Int. J. Environ. Res. Public Health 2015, 12, 11072-11100. [CrossRef] 
38. Admi, H.; Eilon-Moshe, Y. Do hospital shift charge nurses from different cultures experience similar stress? An international cross sectional study. Int. J. Nurs. Stud. 2016, 63, 48-57. [CrossRef]

39. Radkiewicz, P.; Widerszal-Bazyl, M.; Pokorski, J. Dlaczego pielegniarki tak wcześnie odchodzą z zawodu? Bezp. Pr. 2004, 7/8, 31-34.

40. Selander, J.; Bluhm, G.; Nilsson, M.; Hallqvist, J.; Theorell, T.; Willix, P.; Pershagen, G. Joint effects of job strain and road-traffic and occupational noise on myocardial infarction. Scand. J. Work. Environ. Health 2013, 39, 195-203. [CrossRef] [PubMed]

41. Salska, A.; Chiżyński, K.; Salski, W.; Wiszniewska, M.; Walusiak-Skorupa, J. Choroby układu krążenia związane z praca zawodową istotny problem zdrowotny osób pracujących. Choroby Serca i Naczyń 2015, 12, 75-87.

42. Yau, Y.H.C.; Potenza, M.N. Stress and Eating Behaviors. Minerva Endocrinol. 2013, 38, $255-267$.

43. Nahm, E.-S.; Warren, J.; Zhu, S.; An, M.J.; Brown, J. Nurses' self-care behaviors related to weight and stress. Nurs. Outlook. 2012, 60, e23-e31. [CrossRef]

44. Itzhaki, M.; Peles-Bortz, A.; Kostistky, H.; Barnoy, D.; Filshtinsky, V.; Bluvstein, I. Exposure of mental health nurses to violence associated with job stress, life satisfaction, staff resilience, and post-traumatic growth. Int. J. Ment. Health Nurs. 2015, 24, 403-412. [CrossRef] [PubMed]

45. Gabriel, A.S.; Diefendorff, J.M.; Erickson, R.J. The relations of daily task accomplishment satisfaction with changes in affect: A multilevel study in nurses. J. Appl. Psychol. 2011, 96, 1096-1104. [CrossRef]

46. Guo, Y.F.; Cross, W.; Plummer, V.; Lam, L.; Luo, Y.H.; Zhang, J.P. Exploring resilience in Chinese nurses: A cross-sectional study. J. Nurs. Manag. 2017, 25, 223-230. [CrossRef] [PubMed]

47. Ang, S.Y.; Uthaman, T.; Ayre, T.C.; Mordiffi, S.Z.; Ang, E.; Lopez, V. Association between demographics and resilience: A cross-sectional study among nurses in Singapore. Int. Nurs. Rev. 2018, 65, 459-466. [CrossRef] [PubMed]

48. Zheng, Z.; Gangaram, P.; Xie, H.; Chua, S.; Ong, S.B.C.; Koh, S.E. Job satisfaction and resilience in psychiatric nurses: A study at the Institute of Mental Health, Singapore. Int. J. Ment. Health Nurs. 2017, 26, 612-619. [CrossRef]

49. Tugade, M.; Fredrickson, B. Resilient individuals use positive emotions to bounce back from negative emotional experiences. $J$. Pers. Soc. Psychol 2004, 86, 320-333. [CrossRef] [PubMed]

50. Gao, T.; Ding, X.; Chai, J.; Zhang, Z.; Zhang, H.; Kong, Y.; Mei, S. The influence of resilience on mental health: The role of general well-being. Int. J. Nurs. Pract. 2017, 23, e12535. [CrossRef]

51. Garcia-Izquierdo, M.; Meseguer de Pedro, M.; Rios-Risquez, M.I.; Sanchez, M.I.S. Resilience as a moderator of psychological health in situations of chronic stress (burnout) in a sample of hospital nurses. J. Nurs. Scholarsh. 2018, 50, 228-236. [CrossRef]

52. Masao, G.; Hiroshi, I.; Hiroyuki, O. The relationship of resilience, hardiness, depression and burnout among Japanese psychiatric hospital nurses. J. Nurs. Educ. Pract. 2013, 3, 12-18. [CrossRef]

53. Mealer, M.; Jones, J.; Moss, M. A qualitative study of resilience and posttraumatic stress disorder in United States ICU nurses. Intensive Care Med. 2012, 38, 1445-1451. [CrossRef] [PubMed]

54. Ogińska-Bulik, N. Prężność psychiczna a zadowolenie z życia osób uzależnionych od alkoholu. Alcohol. Drug Addict. 2014, 27, 319-324. [CrossRef]

55. Chanduszko-Salska, J. Psychologiczne uwarunkowania nadmiernego zaabsorbowania jedzeniem. Psychiatria 2013, 10, 1-8.

56. Ogińska-Bulik, N. Szkoła jako środowisko kształtowania psychologicznych zasobów jednostki chroniących przed podejmowaniem zachowań ryzykownych-rola prężności. In Szkoła Jako śRodowisko Edukacji Zdrowotnej; Bilski, D., Ed.; WSEZiNS: Lodz, Poland, 2010; pp. 21-35.

57. Grafton, E.; Gillespie, B.; Henderson, S. Resilience: The power within. Oncol. Nurs. Forum. 2010, 37, 698-706. [CrossRef] [PubMed]

58. Goniewicz, K.; Goniewicz, M.; Burkle, F.M.; Khorram-Manesh, A. Cohort research analysis of disaster experience, preparedness, and competency-based training among nurses. PLoS ONE 2021, 16, e244488. [CrossRef] 